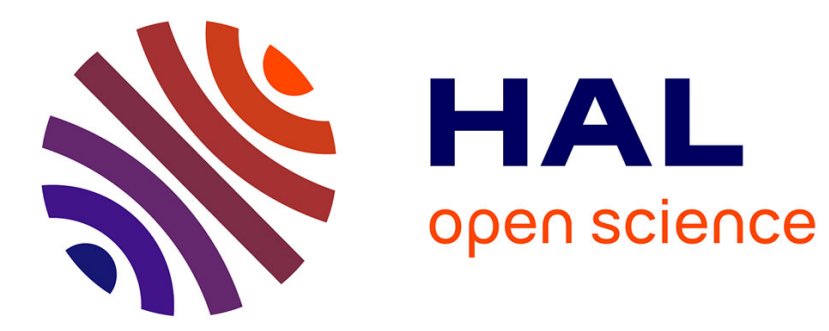

\title{
UK defence change and the impact on supply relationships
}

Thomas Johnsen, Mickey Howard, Joe Miemczyk

\section{To cite this version:}

Thomas Johnsen, Mickey Howard, Joe Miemczyk. UK defence change and the impact on supply relationships. Supply Chain Management: An International Journal, 2009, 14 (4), pp.270-279. 10.1108/13598540910970108 . hal-00771092

\section{HAL Id: hal-00771092 \\ https://hal.science/hal-00771092}

Submitted on 4 Sep 2013

HAL is a multi-disciplinary open access archive for the deposit and dissemination of scientific research documents, whether they are published or not. The documents may come from teaching and research institutions in France or abroad, or from public or private research centers.
L'archive ouverte pluridisciplinaire HAL, est destinée au dépôt et à la diffusion de documents scientifiques de niveau recherche, publiés ou non, émanant des établissements d'enseignement et de recherche français ou étrangers, des laboratoires publics ou privés. 


\title{
UK DEFENCE CHANGE AND THE IMPACT ON SUPPLY RELATIONSHIPS
}

\author{
Thomas Johnsen, \\ Audencia Nantes Ecole de Management, \\ 8 Route de la Joneliere, \\ BP 31222 - 44312 Nantes Cedex 3. \\ E-mail: tjohnsen@audencia.com \\ Tel: + $33(0) 240374625$ \\ Mickey Howard, \\ Operations \& Supply Group, \\ University of Bath School of Management, \\ Bath, BA2 7AY, UK. \\ E-mail: M.B.Howard@bath.ac.uk \\ Tel: +44(0)1225383682 \\ Joe Miemczyk, \\ Audencia Nantes Ecole de Management, \\ 8 Route de la Joneliere, \\ BP 31222 - 44312 Nantes Cedex 3. \\ E-mail: jmiemczyk@audencia.com \\ Tel: + 33 (0)240374625
}




\section{Abstract}

Purpose: Evaluates the changing patterns of defence requirements and their implications on supply chains and relationships within the UK defence industry.

Design/methodology: Builds a case study on the UK defence industry comprising 22 face-toface interviews with senior management from the Ministry of Defence (MoD) and major first tier suppliers, as well as senior officers in the British armed forces.

Findings: Suggests that there are major changes currently taking place that have major impacts on defence supply relationships. We find a consensus in the industry concerning a shift towards Through-Life Management (TLM), where major equipment platforms are kept in service for several decades. TLM is widely acknowledged as requiring much closer partnerships in the defence supply chain, in which suppliers assume much greater responsibilities in areas such as in-service support and maintenance. Yet the findings with $\mathrm{MoD}$ and suppliers reveal different perceptions of the feasibility and practical implications of the proposed changes.

Practical implications: Product-service specific capabilities need to be developed especially in areas such as accurate lifecycle costing. The development of integrated supply partnerships requires greater emphasis on openness, risk and reward sharing, trust and long-term commitment in supplier relationships. There is also a need for early supplier involvement to ensure not only design for manufacture, but design for maintainability and logistics, instigated and managed by the customer (i.e. MoD).

Originality/value: The analysis demonstrates the importance of adopting a through-life perspective when considering industrial contexts characterized by very long product lifecycles. Our study shows that a through-life perspective creates a blurring of the boundary between customers and suppliers, and increases long-term supplier responsibility. This gives rise to new considerations, such as sophisticated risk and rewards sharing mechanisms, design for maintainability, and technology insertion.

Keywords: defence industry, supply relationship, supply chain, through-life management, design for maintainability

\section{INTRODUCTION}


The restructuring of the UK defence acquisition system, announced as part of the 1998 Strategic Defence Review (SDR, 1998) and followed up with 'The New Chapter' (SDR, 2002), 'Defence Industrial Strategy’ (MoD, 2005) and Defence Technology Strategy (MoD, 2006) has created a new industrial context for suppliers and sub-tier contractors of military equipment. Traditionally logistics, procurement and supply were organized by each service individually. However, the 1998 SDR heralded major changes in the way in which the UK Ministry of Defence (MoD) buys and maintains equipment, and supports the armed forces. A key development was the announcement by the Secretary of State in 1999 of the launch of the Defence Logistics Organization (DLO) and the Defence Procurement Agency (DPA), followed by their more recent merger into the Defence Equipment \& Support organization in 2006. A core element of the defence restructuring programmes has been an emphasis on the development of strategic long-term supply relationships - or partnerships - between defence customers and suppliers. Major supply partners are now expected to take on significant responsibilities throughout the so-called CADMID (Concept, Assessment, Design, Manufacture, In-service, and Disposal) cycle; supplier responsibilities for managing specific product/service platforms, such as aircraft or ships, on behalf of the MoD are anticipated to stretch for several decades. The concept of through-life management (TLM) is used in defence circles to describe the management of the product-service lifecycle throughout the CADMID cycle (MoD, 2005). The MoD understand that this requires a new way of working with suppliers, yet in many ways it appears to be uncharted territory for the defence industry.

In academic literature the trend towards long-term strategic supplier relationships is well documented across a range of industries, including private sector manufacturing (e.g. Sako; 1992; Lamming, 1993; Dyer and Singh, 1998, Cousins, 2002), and more recently both private and public sector service industries (e.g. Cox et al, 2004; Doran et al, 2005; Zheng et al, 
2008). However, the defence industry is idiosyncratic in several respects: domestic suppliers are prioritized due to national strategic defence priorities; defence procurement involves very long-term contracts with suppliers of highly complex long-life equipment; and it remains a controversial yet influential business for most Western countries (Freedman, 2007; Barker, 2007). Whereas there is much debate about the need for partnership supplier relations in defence circles (e.g. MOD, 2005; 2006), there is little research in the management literature on defence industry supplier relations. Yet the defence industry could well be in the process of taking the partnership model further than most other industries (Tatham, 2005). The shifting supplier responsibilities throughout the CADMID cycle highlights the need for advanced and complex partnership arrangements including mechanisms for risk and reward sharing, strategic alignment, transparency, commitment and so on, which may go beyond what is normally experienced in other industries. However, how these supplier relationships are supposed to function in the changing defence industry is all but clear (Croft et al, 2001). While the publication of the DIS white paper in December 2005 by the then UK defence procurement minister Lord Drayson presented a vision of closer collaboration between public and private sector organizations (MOD, 2005), doubts persist over how the changing UK defence environment will affect the relationship between defence suppliers and the MoD, and the practical implementation of a new supply strategy in the short or even medium term.

This paper evaluates the implications of changes to industrial supply strategy in the defence industry. In particular it explores the changing patterns of defence requirements and the implications on supply relationships within the UK defence industry. The paper builds a case study on the UK defence industry comprising 22 face-to-face interviews with senior management from the $\mathrm{MoD}$ and prime suppliers, as well as senior officers in the British armed forces. 
The paper is structured as follows: The next section briefly reviews the literature on supply relationships with a particular focus on the concept of long-term supply relationships, or 'partnerships'. The third section describes the methodology employed for the data collection. The fourth section reports the findings from our case study. The fifth section discusses the empirical findings in the light of the changing nature of supply relationships. The paper concludes with an outline of conceptual and managerial implications.

\section{LITERATURE REVIEW}

The most important trend within the last two decades or so has arguably been a shift towards long-term strategic supplier relationships or 'partnerships' (e.g. Macbeth and Ferguson, 1994; Cousins, 2002). However, the partnership concept is so widely used - and misused - that it sometimes ceases to mean anything: a sound definition of partnerships is required. A useful starting point is Mohr and Spekman (1994) who define partnerships as "purposive strategic relationships between independent firms who share compatible goals, strive for mutual benefit, and acknowledge a high level of mutual interdependence". The keyword here is mutuality, most often used to refer to common goals and interests that bind firms in a shared purpose (Ford et al, 1986). Mohr and Spekman's (ibid) definition also suggests that mutual benefit implies shared benefits. Equitable sharing of not only risks but also rewards is often regarded as critical to successful alliances and partnerships (Stuart and McCutcheon, 1996). The focus on purposive strategic relationships indicates that partnerships are created deliberately and that they only concern a proportion of a firm's range of relationships. Accordingly, partnerships do not have to be formalized, but are indeed often characterized by a degree of informality (Blau, 1964; Håkansson and Snehota, 1995). Nevertheless, firms are 
likely to make deliberate efforts to classify the nature of its range of relationships, distinguishing those that are strategically important from those of more tactical or operational importance. The widespread application of purchasing and supplier relationship portfolio models across industries reinforces the importance of structuring a firm's supply base in such a way that only a small proportion of a firm's suppliers are considered strategic partners; this is often those reflecting the highest value and risk (Kraljic, 1983; Olsen and Ellram, 1997; Gelderman and van Weele, 2005).

Mohr and Spekman (ibid) go on to suggest that partnerships imply four attributes: commitment, coordination, interdependence and trust. A plethora of such attributes are suggested in the literature but these four appear to be accepted across different schools of thought of buyer-supplier relationships (e.g. Anderson and Narus, 1995; Pfeffer and Salancik, 1978; Wilson, 1995; Lambert et al, 1996). An underlying characteristic is the long-term nature of partnerships. For example, commitment and trust develop gradually over a long period of time even though both may be ruined in an instant through opportunistic behaviour (e.g. Blau, 1964; Gundlach et al, 1995; Sako, 1994). Long-term adaptation processes are also a central theme in the seminal interaction model developed by the Industrial Marketing and Purchasing (IMP) group (e.g. Ford et al, 1986; Håkansson and Snehota, 1995). Their model suggests that adaptations often take place to the extent that high degrees of mutual dependency are formed and behavior eventually becomes institutionalized and predictable, which again demonstrates commitment and trust (Cousins, 2002). The IMP approach, however, does not assume close relationships or partnerships, but emphasizes the heterogeneous nature of buyer-supplier relationships (Ford et al, ibid). 
Associating partnerships with tranquil relationships may be dangerous. Cousins (2002) argued that there is no such thing as partnerships; instead firms have a range of relationships with different levels of collaboration, although his definition of strategic relationships, exhibiting mutual dependence and a high degree of certainty (trust), effectively equate to partnerships. But often customers and suppliers do not share the same view, and classification, of the same relationship (Giannakis, 2007), and dependency can become a one-way street fostering opportunistic behaviour as one party takes advantage of its superior power (Cousins, ibid; Emerson, 1962). Power and conflict remain critical features of supply relationships even if sheer power exploitation seems less appropriate in a collaborative context (Cox et al, 2004). In a similar criticism of the concept of partnerships Lamming (1993) stressed the competitive as much as the collaborative nature of partnerships. He argued that the form of partnerships, as adopted by Western automakers, often lack the important mutual dimension, and that mutuality actually does not exist in many established best practices associated with supply chain management (Lamming, 1996). For instance, the practice of open book negotiation implies open exchange of (cost) information, yet in practice it is flawed as it usually involves a one-sided effort by the customer to ensure that its suppliers do not over-charge the customer (ibid). Assuming a high degree of trust and commitment, Lamming et al (2005) conceptualized cost transparency as a two-way information flow of cost information between customer and supplier to make it possible for the two parties to work together to reduce costs. Cost (or value) transparency (ibid) echoes the need for open exchange of information and knowledge, shared in an accurate, timely and relevant manner, which is highlighted in much literature (e.g. Dyer and Nobeoka, 2000; Womack et al, 1990; Hines et al, 2000; Mohr and Spekman, 1994; Giannakis, 2008).

The current situation with regard to supply chain relationships within the UK defence industry is one which is both exacerbated, and driven by, significant overstretch of MoD operating 
budgets (i.e. conflict in Iraq and Afghanistan) and commitment to longstanding capital equipment plans (e.g. Eurofighter/Typhoon, Future Carrier/CVF). This places considerable pressure on the MoD to reduce costs by outsourcing maintenance of ancillary infrastructure and frontline support, whilst maintaining military effectiveness in the face of spiraling technology prices and growing activity from international terror organisations. Although Public-Private Partnerships and Private Finance Initiatives are now a well established mechanism for industry leadership (Hall, 2007), the vision for partnering core defence supply chains as laid out by the Defence Industrial Strategy white paper (2005) has never been fully realized. Despite the much anticipated publication of the Defence Technology Strategy paper in 2006, and localized success in the early phases of the future carrier and lightweight armoured vehicle projects, no universal defence model involving buyer-supplier collaboration has emerged - 'partnership' or otherwise. As the MoD develops its policy of through-life capability management by building on existing concepts such as Lean Transformation and Smart Acqusition, considerable further development is needed to meet the long-term design, build, and in-service support challenges of the $21^{\text {st }}$ century military supply chain: “...efficient in peace but effective in war" (Tatham, 2005).

The literature review suggests that although there has been a trend towards long-term collaborative supply relationships, it may be problematic to label these as 'partnerships'. Real partnerships involve a high degree of mutuality and interdependence and are characterized by commitment, coordination, interdependence and trust developed over a long period of time (Pfeffer and Salancik, 1978; Lamming, 1993; Mohr and Spekman, 1994; Anderson and Narus, 1995; Wilson, 1995; Lambert et al, 1996). The IMP interaction approach and purchasing portfolio models highlight the variegated nature of supply relationships and that only a small proportion of supply relationships can be regarded as strategic partnerships (Ford et al, 1986; Håkansson and Snehota, 1995). Supply relationships are about power and conflict 
as much as they are about collaboration, although one would expect a change towards a 'partnership' approach to involve a shift away from adversarial behaviour towards a model where collaboration and mutuality are blended with openness and transparency (Sako, 1994; Gundlach et al, 1995; Cousins, 2002). Hence this study seeks to explore the following research question: How do the changing patterns of demand affect the nature of relationships between defence suppliers and the MoD, especially in terms of the need for mutuality and transparency within strategic partnerships?

\section{METHODOLOGY}

Supply relationship strategies in the UK defence sector is not a topic that has been extensively researched, and it is inherently a complex, dynamic and highly sensitive topic (Croft et al, 2001). Therefore, we decided to adopt an exploratory case study research strategy (Yin, 2003; Voss et al, 2002; Seuring, 2008), focusing on the UK defence sector as the unit of analysis (Pettigrew and Whipp, 1991). This implies that the sector constituted our single in-depth case study and not individual companies. The defence sector is relevant to choose as a single case study, especially if viewed as an 'extreme case' (Pettigrew and Whipp, ibid), although we acknowledge that this presents a problem of generalizability, an issue that we discuss later.

Prior to launching the in-depth case study we conducted a scoping study that involved 5 interviews with managers and senior armed forces officers within the MoD and suppliers (Table 1). These exploratory open-ended interviews helped to refine our research questions and general understanding of the main drivers of change within the industry and how they affected purchasing and supply management structures and processes within the industry. Building on the lessons from the scoping study and a review of the literature we commenced 
the data collection for the in-depth case study. Face-to-face interviews were conducted and compared with archival documentation such as government white papers.

\section{INSERT TABLE 1}

Interviews were conducted with several organizations with the UK defence sector in order to gain a variety of perspectives from within the MoD and the supply base. In total we carried out 17 semi-structured interviews, each lasting approximately 2 hours. A protocol of semistructured questions were prepared for the interviews, derived from the literature review and the scoping study (Appendix A). The development of trust was critical to assure respondents of the use of the information and insights they provided, hence all names of individuals have been concealed in this paper. Further, in the discussion of the findings we have disguised the names of individuals and the organisations that they represent, and only refer to these as 'MoD' or 'suppliers'.

The interviewees were selected by means of reputational sampling (i.e. experts in the field highlighted appropriate personnel, Miles and Huberman, 1994). This reputational sampling resulted in interview coverage of major elements of the defence sector. Thus, we were able to cover through interviews a significant proportion of the key players in the UK defence industry, including key parts of the MoD (e.g. Defence Procurement Agency, Defence Logistics Organisation), and major suppliers with whom the MoD has formal strategic partnership arrangements including BAE Systems, Thales, Augusta-Westland, and QinetiQ.

Interview transcripts and/or summaries were read and interpreted by 3 research team members. Interview summaries and notes were complemented with documentary data and any 
informational residue (Lincoln and Guba, 1985). Matrices were constructed and used as coding frameworks (Miles and Huberman, 1984), comparing and contrasting individual actor interpretations; for confidentiality reasons these are presented here in aggregated form i.e. 'MoD', 'Suppliers', and 'Official Documents' (Table 2). The latter served to corroborate MoD interviews and vice versa, whereas supplier interviews in many cases provided a rather different perception of reality in the UK defence industry. The rigour and validity of the findings were ensured through the following steps (Eisenhardt, 1989; Yin, 1989). Firstly, follow-up interviews were held with several respondents to enquire about areas of ambiguity and confirm interpretations and emerging conclusions. Secondly, we sought respondent validation (Reason and Rowan, 1981) by returning interview summaries to respondents for comments and clarifications. Thirdly, we presented the analysis to 2 organisations involved in the project (1 public and 1 private) to generate further discussion around any remaining areas of ambiguity.

\section{RELATIONSHIP CHANGE BETWEEN DEFENCE SUPPLIERS AND MOD}

The findings are primarily discussed around the results of the 22 interviews conducted as part of the data collection. This section structures the findings into four main themes that emerged from the analysis. The first sub-section presents the findings on the change towards strategic partnerships and the shifting boundaries between the various parts of the MoD and suppliers. Subsequently, the main emerging themes around TLM, openness and transparency, and mutuality and risk and benefit sharing are discussed. Table 1 provides an overview of the findings, divided into three main respondent groups: suppliers, MoD and 'official documents'.

\section{INSERT TABLE 2}




\section{Change towards strategic partnerships: shifting boundaries}

The concept of partnership suppliers is widely accepted within the defence industry as the best way forward, and during interviews it was evident that the need to partner with the MoD is recognized across the MoD and the supply base. The industry distinguishes formally between 'partnering arrangements' and 'partnering agreements', the former implying a nonlegal arrangement that can be applied to any contractual relationship, whereas the latter implies a formal "legally binding, collaborative entity" (MoD, 2005, p134). Partnership agreements are evident, for instance, in the development of the relationship between the MoD and major suppliers including BAE Systems, Wallop Defence Systems, QinetiQ, and AgustaWestland. In comparison, partnership arrangements appear to be more widely pursued with a range of suppliers.

Both the MoD and the major strategic partners have been rationalizing their supply bases to increase the value of contracts by focusing on fewer, more critical supply relationships. Single or dual sourcing is becoming more popular, both within MoD and the supply base. Suppliers recognize that the increased dependence on fewer suppliers will require better relationship management, although some suppliers are unclear of how to best proceed with relationship management.

Despite the MoD's intentions to foster close partnerships the findings suggest that the roles in managing the MoD-supplier interfaces are unclear. It appears that the meaning of the 'customer' is far from well-developed and that suppliers are often confused by the fragmentation of the MoD. It has recently appointed Key Supply Engagement Managers (KESMs) at senior level to interface with the largest and most critical suppliers (MoD 
Acquisition Handbook 2005). These positions have been developed to improve the MoD's understanding of the defence supply base and to play a key role in forming stronger partnerships with selected suppliers. KESMs are also responsible for supplier performance assessment and should therefore also play a role in influencing behaviours within the MoD as well as the supply base. This may in due course help the MoD to overcome problems of organizational fragmentation, including issues of coordination between DLO and DPA, as identified by several respondents.

Strategic alignment seems to be a strong feature of the partnerships that the MoD clearly seek to foster and was described by MoD respondents as "the glue that keeps partners together". Indeed the DLO sees future procurement and supply organization shifting from 'fixed contract' towards a 'dynamic boundary' between MoD and industry. The ideal dynamic boundary will require shared processes and partnering. As major suppliers gain responsibility for in-service support, the boundary between the MoD and these suppliers, and the contractors they in turn use to carry out in-service support, becomes increasingly blurred, not least as contractors often use ex-service personnel.

The boundary between the MoD, suppliers and contractors thus seem to be increasingly blurred, and it raises a range of questions about, for instance, ownership, responsibility, and cost. Yet, it is certainly clear that partnership supplier relations are particularly pertinent in the UK defence industry due to the recent focus on supplier responsibility in in-service support and TLM. These issues are further discussed in the following sections.

\section{Change towards TLM and in-service support}


One of the most significant changes in the UK defence industry is undoubtedly the shift towards so-called 'in-service support' and TLM. Indeed, the concept of TLM fundamentally alters the relationship between the MoD and its strategic suppliers. The Defence Industrial Strategy White Paper in 2005 emphasizes the need for through-life capability management (TLCM) based on open product architectures, allowing upgrading and support: TLCM reflects the shift away from successive generations of platform-orientated programmes "leaps of capability with major new procurements or very significant upgrade packages" towards:

" a capability based approach... a new paradigm centred on support, sustainability and the incremental enhancement of existing capabilities from technology insertions" (MoD, 2005, p17).

The most extreme example of the extended use of platforms is the B52 bomber used by the US Air Force, originally designed in 1949, but planned to continue to see active service until 2050, by which time it will be a 100 year old airframe design. This implies that although innovation in the UK defence industry is considered critical, it will mainly happen through the continuous upgrading of existing technology platforms rather than the development of major new platforms. As one supplier put it: 'We're likely to see new technology on 60 year old platforms e.g. Sea King and Lynx helicopters.'

We identify a need for 'design for maintainability' rather than design for manufacture as a key driver of future innovation and design, because of the increasing need to keep product platforms in-service for several decades or more. 'Technology insertion' (or capability insertion) is the concept used to describe the continuous upgrading of old platforms with new technologies (or capabilities) such as IT software. In defence terms the concept of TLM is captured in the lifecycle model 'Concept, Assessment, Demonstration, Manufacture, In- 
service, Disposal' (CADMID - see Figure 1). Behind this model is an anticipation that industrial relationships should change, to enable this new focus, through long term, 'assured' relationships.

\section{INSERT FIGURE 1}

Through-life capability means a shift over the past 20 years from defence contractor's responsibility ending after they had built to the blueprint towards "much more intrusive relationships" involving the MoD "buying capability" rather than equipment. As explained by one MoD respondent this refers to the:

“..sum of all the 'lines of development' i.e. not just a ship, but people who are trained and organized to fight the ship effectively and the logistics and infrastructure to support it”.

Interviews with suppliers likewise reveal recognition of the concept of 'capability buying and selling': “We're not selling products, we're selling capability". Some defence suppliers point out that the distinction between terms such as 'contracting for availability' and 'contracting for capability' is increasingly important for contractors during periods of volatile demand. Contracting for availability means supplier responsibility for delivering platforms and equipment limited to an agreed performance and outputs standard. Contracting for capability means overall responsibility for providing capability (e.g. air refuelling) and outputs to an agreed performance standard (MoD, 2005, p135). 
Suppliers therefore seem to appreciate the significance of the TLM concept. As one supplier phrases it: '...as much of our business is in through-life as in new-build business'. Suppliers also believe that TLM has significant impacts on profitability due to the shift away from selling parts with a limited life towards extending the life of parts and providing the required levels of availability and capability. However, many of the implications of TLM seem unclear to suppliers, for example, suppliers do not completely understand the full cost implications of TLCM and several suppliers seek a common definition.

\section{Change towards transparency and openness}

A dominant theme within several white papers and industry reports, which is regarded as a core ingredient of working in partnership with major suppliers, is the need for transparency and openness. The DIS paper explicitly sets out to encourage trust, openness, transparency and communication at all levels between the MoD and its partnership suppliers (MoD, 2005, p. 11), and the MoD intends for such partnership relations to cascade down the supply chain i.e. to prime contractors and SMEs: “...procurement would be through cooperative working with the Group, in the spirit of openness and transparency, where there could be open and full discussion of all relevant data by all parties on an on going basis" (MoD, p. 51). The MoD's Acquisition Handbook (2005, p. 28) similarly states that the MoD seek to: "Value openness and transparency; share future plans and priorities wherever possible to encourage focused investment and avoid wasted effort."

The DIS paper further states that transparency relates to the MoD's “capability intentions (within obvious security considerations), clarity of affordability constraints and better articulation of the desired enterprise outcome" (MoD, 2005, p. 113). Nevertheless, interviews 
with the MoD and suppliers reveal some of the difficulties of achieving transparency in practice. Some of the respondents from the MoD point to the particular difficulties of sharing data and technology with any non-UK partners, but the UK suppliers that we interviewed also suggest that the relationship between the MoD and suppliers has not always been easy. Indeed, one supplier states that there is: "an inherent lack of trust of the MoD: suppliers know [they are going to get] ripped off - they know that instinctively."

The extensive use of contracts in the defence sector is also perceived by some stakeholders to inhibit trusting relationships: as one supplier put it: "If there were more trust we wouldn't need four inches of contract!". Therefore, it seems that an ethos of a high level of openness and transparency will take a long time to develop and involve considerable pain and great efforts to begin to change ingrained behaviours.

\section{Change towards mutuality and risk and benefit sharing}

The shift towards strategic alignment discussed earlier emphasizes the focus on mutuality in relationships between the MoD and key suppliers. The view is that alignment will require industry visibility of MoD resource plans and the MoD will need visibility of the industry business model: there will be much need for shared processes and partnering, especially as major suppliers gain responsibility for in-service support. There is also a perceived need for a total cost of ownership approach to costing as suppliers are required to guarantee "end-to-end service provision."

Traditionally, however, there have been disincentives for suppliers to pay for repairs. Consequently, as suppliers take on more responsibility they seek new arrangements for sharing of gains, costs as well as risks: suppliers are dissatisfied with fixed price 
arrangements. The MoD recognizes that planning needs to be around whole-life costing and capability rather than simple upfront purchase cost. MoD reports suggest use of incentivization of gain sharing to encourage industry and MoD to improve performance. Nevertheless, some suppliers are worried that contractors will find savings to the detriment of air safety, and that suppliers are not incentivized to over-maintain military aircraft as has traditionally been the case in the past.

Nevertheless, general policy is to keep markets open, not just rely on one prime contractor. The defence communication market, for example, is still quite open at this time. This shift in supply chain strategy means a fundamental shift in the relationship between the MoD and industry. In simple terms it means a shift from singular, linear, static, formal and onedimensional relationships, towards multiple, non-linear, dynamic, partnered and multidimensional relationships.

\section{DISCUSSION AND CONCLUSION}

The findings suggest that there are major changes currently taking place that have significant impacts on defence supply relationships. Whilst official industry reports issued by UK government departments set out a vision for the industry that will shape future relationships between the MoD and its supply base, interviews with MoD and major suppliers reveal rather different perceptions of the feasibility and practical implications of the proposed changes. These widely different perceptions supports the model by Giannakis (2007) that emphasises the need to analyse both buyer and supplier perceptions in order to fully understand relationship dynamics. 
The most important trend in MoD-supplier relationships is the shift towards TLM and TLCM. There are currently structural changes of vertical disintegration and supply base consolidation that evidently call for more intensive and fluid relationships between the MoD and its key suppliers. The MoD strongly pursues the concept of partnership supplier relations, and promotes greater transparency, strategic alignment, and risk and gain sharing within its core relationships. These are core ingredients of successful partnerships (Mohr and Spekman, 1994; Stuart and McCutcheon, 1996) so the MoD seems to be justified in pursuing these goals. However, as suggested by several respondents 'open book' relations can be problematic and relationships often do not appear to reflect high degrees of mutuality (Lamming, 1993) despite the focus on strategic alignment. Indeed, as argued by Lamming et al (2005) cost transparency in the form of traditional open book negotiation (or open book accounting) may do little to foster closer and more integrated supply relationships, as suppliers may perceive this as merely an attempt to squeeze cost out of 'their end' of the supply chain thereby putting them at increased risk. Furthermore, any move towards implementation of cost transparency requires high levels of trust within supply relationships (e.g. Sako, 1994), and high levels of trust evidently do not exist universally within the UK defence supply chain.

\section{Conceptual implications}

The main conceptual implication of our study concerns TLM, which is a relatively immature concept in the mainstream management literature. Research within logistics and service management on, for example, customer support (Goffin, 1999) and aftermarket support (Armistead and Clark, 1991) echoes the integration by manufacturers of services into their core product offerings: what some have coined 'servitization' (Vandermerwe and Rada, 1988). However, the lifecycle view reflected by the concept of TLM offers a new perspective, 
especially when taking into account that it is applied in a context of very long product lifecycles. Our study suggests that this trend causes a blurring of the boundary between customers (here MoD) and suppliers, and that suppliers' increasing responsibility throughout the CADMID cycle creates a need for sophisticated risk and rewards sharing mechanisms (Cox et al, 2004). We also propose a need for what we here term 'design for maintainability' rather than design for manufacture: shifting the focus during the design and development stage towards long-term maintenance and serviceability.

Closely connected to TLM is the concept of technology (or capability) insertion. We tend to assume that product lifecycles are becoming increasingly shorter, whereas in fact they are becoming longer in some industries. Yet, the concept of technology insertion appears to have been applied very sparsely in the literature so far. Our study has highlighted its significance in the defence industry, and the need for supply partners in maintaining long-term platforms would not appear to be unique to the defence sector: one might expect to encounter similarly long-term platforms or product lifecycles in, for example, civil aerospace, trains or ship building. Although it is difficult to generalize from a study of an industry as idiosyncratic as defence, many of these concepts are clearly relevant in other industries characterized by longterm product platforms. There is scope for much further research in this area.

\section{Managerial implications}

Where firms are considering a greater role in 'in-service support', product-service specific capabilities need be developed especially in areas such as accurate lifecycle costing (for the development phase), or the ability to adapt to changing demand requirements over the product-service lifecycle. This can be expected to place even greater emphasis on levels of openness, risk and reward sharing, trust and long-term commitment in supplier relationships. 
Suppliers need to develop a broader range of capabilities to cope with the requirements from the MoD to take wider responsibility throughout the CADMID lifecycle. Suppliers are increasingly required to assume a higher degree of responsibility during the latter stages of CADMID, taking a greater role in customer-facing and frontline activity and in-service support. Therefore, supplier involvement during the early part of the CADMID cycle, especially product development (Petersen et al, 2005), is key to ensure not only design for manufacture but also design for maintainability and logistics. This implies that the MoD is more likely to require suppliers to take a wider 'black box' responsibility (Koufteros, 2007) involving the entire product-service offering, and the MoD will need to enable suppliers to assume this higher level of responsibility.

Increasing supplier responsibility throughout the defence product lifecycle will undoubtedly require development of more integrated supply partnerships. The idea of partnership suppliers is widely accepted within the industry as the best way forward, but whilst the MoD's 2005 defence industrial strategy document explicitly sets out to encourage transparency and openness, risk and gain/reward sharing, development of goal congruence and development of trust, our findings suggest that adopting these elements will require much more effort on behalf of both the MoD and the supply base.

\section{REFERENCES}

Anderson, J. and Narus, J. (1995), "Capturing the value of supplementary services", Harvard Business Review, Jan/ Feb, pp. 75-83.

Armistead, C. and Clark, G. (1991), "A framework for formulating after-sales support strategy", International Journal of Physical Distribution \& Logistics Management, Vol. 21 No 9, pp. 22-29.

Barker, A. (2007). “ $£ 15$ bn sought for military. Flattering to deceive on Defence spending”. Financial Times, $12^{\text {th }}$ Dec.

Blau, P. (1964), Exchange and power in social life, New York: John Wiley. 
Cousins, P.D. (2002), "A conceptual model for managing long-term inter-organisational relationships", European Journal of Purchasing and Supply Management, Vol. 8 No. 2, pp. 71-82.

Cox, A., Watson, G., Lonsdale, C. and Sanderson, J. (2004), "Managing appropriately in power regimes: relationship and performance management in 12 supply chain cases", Supply Chain Management: An International Journal., Vol. 9 No. 5, pp. 357 - 371.

Croft, S., Dorman, A., Rees, W. and Uttley, M. (2001), Britain and Defence 1945 - 2000 A Policy Re-evaluation. Longman: Harlow UK.

Doran, D., Thomas, P. and Caldwell, N.D. (2005), "Examining buyer-supplier relationships within a service sector context", Supply Chain Management: An International Journal, Vol. 10 No. 4), pp 272-277.

Dyer, J. and Nobeoka, K. (2000), "Creating and managing a high performance, knowledge sharing network: the Toyota case", Strategic Management Journal, Vol. 21, pp. 345-367.

Dyer, J. and Singh, H. (1998). "The relational view: cooperative strategy and sources of interorganizational competitive advantage". Academy of Management Review. 23 (4) pp. 660679.

Eisenhardt, K.M. (1989), "Building theories from case study research", Academy of Management Review, Vol. 14 No. 4, pp. 532-550.

Emerson, R.M. (1962), "Power-dependence relations", American Sociological Review, Vol. 27 No. 1, pp. 31-41.

Ford, D. and Håkansson, H. and Johanson, J. (1986), "How do companies interact?", Industrial Marketing and Purchasing, Vol. 1 No. 1, pp. 26-41.

Freedman, L. (2007). "Constant combat is draining our forces and their budget." The Times. 24 Nov, pp7.

Gelderman, C.J. and van Weele, A.J. (2005), "Purchasing portfolio models: a critique and update”, The Journal of Supply Chain Management, Vol. 41 No. 3, Summer, pp. 19-28.

Giannakis, M. (2007), "Performance measurement of supplier relationships", Supply Chain Management: An International Journal, Vol. 12, pp. 400-411.

Giannakis, M. (2008), "Facilitating learning and knowledge transfer through supplier development", Supply Chain Management: An International Journal, Vol. 13, pp. 62 - 72.

Goffin, K. (1999), "Customer Support: A cross-industry study of distribution channels and strategies", International Journal of Physical Distribution and Logistics Management, Vol. 29 No. 6, pp. 374-397.

Gundlach, G.T., Achrol, R.S. and Mentzer, J.T (1995), "The structure of commitment in exchange", Journal of Marketing, January, pp. 78-92.

Hall, P. (2007). Defence Procurement, Innovation and the National Innovation System. Manchester Business School. Working Paper No. 526.

Håkansson, H. and Snehota, I (1995), Developing Relationships in Business Networks, International Thomson Business Press, London.

Hines, P., Lamming., R., Jones., D., Cousins, P. and Rich, N. (2000), Value Stream Management: Strategy and Excellence in the Supply Chain, FT Prentice Hall. 
Koufteros, X.A., Edwin Cheng, T.C., Lai, K. (2007), "Black-box" and "gray-box" supplier integration in NPD: Antecedents, consequences and the moderating role of firm size". Journal of Operations Management, Vol. 25 No. 4, pp. 847-870.

Lambert, Douglas M., Margaret A. Emmelhainz, and John T. Gardner (1996), "Developing and implementing supply chain partnerships", The International Journal of Logistics Management, Vol. 7 No. 2, pp. 1-17.

Lamming, R. C. (1993), Beyond Partnership: Strategies for Innovation and Lean Supply, Prentice Hall.

Lamming, R.C., Caldwell, N.D., Phillips, W.E. and Harrison, D.A. (2005) Sharing sensitive information in supply relationships: the flaws in one-way open-book negotiation and the need for transparency", European Management Journal, Vol. 23 No. 5, pp. 554 - 563.

Lincoln, Y. and Guba, E. (1985), Naturalistic Inquiry. London: Sage.

Macbeth, D. K. and Ferguson, N. (1994), Partnership Sourcing, Pitman, London.

Miles, M. and Huberman, M.A. (1984), Qualitative Data Analysis: a Sourcebook of New Methods, Newbury Pearl and London: Sage.

MoD - Ministry of Defence (2005), Defence Industrial Strategy - Defence White Paper. December, Cm 6697.

MoD - Ministry of Defence (2006), Defence Technology Strategy. UK, Ministry of Defence White Paper December.

Mohr, J. and Spekman, R.E. (1994), "Characteristics of partnership success: partnership attributes, communication behavior, and conflict resolution techniques", Strategic Management Journal, Vol. 15, pp. 135-152.

Olsen, R.F., and L.M. Ellram (1997), “A portfolio approach to supplier relationships", Industrial Marketing Management, Vol. 26 No. 2, pp. 101-113.

Petersen, K. J., Handfield, R. B., and Ragatz, G. L. (2005), "Supplier integration into new product development: coordinating product, process and supply chain design", Journal of Operations Management, Vol. 23 No. 3/4, pp. 371-88.

Pettigrew, A.M., and Whipp, R. (1991), Managing Change for Competitive Success, Basil Blackwell, Oxford.

Pfeffer, J. and Salancik, G.R. (1978), The External Control of Organisations, New York: Harper and Row.

Reason, P. and Rowan, J. (1981), Human Inquiry: A Sourcebook of New Paradigm Research., Chichester: Wiley.

Sako, M. (1992), Prices, Quality and Trust: Interfirm relations in Britain and Japan. Cambridge Univeristy Press.

SDR (1998), Strategic Defence Review White Paper. Report produced by the House of Commons Defence Select Committee, October.

SDR (2002), A New Chapter to the Strategic Defence Review. Report produced by the House of Commons Defence Select Committee.

Seuring, S.A (2008), "Assessing the rigor of case study research in supply chain management", Supply Chain Management: An International Journal, Vol. 13 No. 2, pp. 128137. 
Tatham, P. (2005). "Efficient in Peace but Effective in War: Meeting the Challenge of the Military Supply Chain.” Supply Chain Practice. Vol 7, No 2. pp42-57.

Vandermerwe, S and Rada, J. (1988), "Servitization of business: adding value by adding services", European Management Journal, Vol 6 No 4, pp 314-24.

Voss, C., Tsikriktsis, N., and Frohlich, M. (2002), "Case research in operations management", International Journal of Operations and Production Management, Vol. 22, pp. 195-219.

Wilson, D.T. (1995), “An integrated model of buyer-seller relationships”, Journal of the Academy of Marketing Science, Vol. 23 No. 4, pp. 335-345.

Womack, J., Jones, D. \& Roos, D. (1990) The Machine That Changed The World, Rawson Associates, New York.

Yin, R.K. (2003), Case Study Research: Design and Methods, 3rd ed., Sage Publications, Thousand Oaks, CA.

Zheng, J., Roehrich, J.K. and Lewis, M.A. (2008), "The dynamics of contractual and relational governance: evidence from long-term public-private procurement arrangements" Journal of Purchasing and Supply Management, Vol. 14 No. 1, pp 43-54. 
Table 1: Research Interviews

\begin{tabular}{|c|l|l|c|}
\hline \multicolumn{4}{|c}{ Ro. Scoping study Interviews } \\
\hline \multicolumn{4}{|c|}{ Organization } \\
\hline 1 & Senior advisor to MOD & DERA/QinetiQ & Month / Yr \\
\hline 2 & Senior training officer & Royal Marines & 05.05 \\
\hline 3 & Commander - Flight training & Royal Navy & 05.05 \\
\hline 4 & Commander - Administration & Royal Navy & 06.05 \\
\hline 5 & Lieutenant - Procurement & Royal Air Force & 06.05 \\
\hline \multicolumn{4}{|c|}{ Semi-structured Interviews } \\
\hline 6 & Senior staff officer (Retired) & Royal Navy & 07.05 \\
\hline 7 & Executive director & DPA & 10.05 \\
\hline 8 & Senior staff officer & Army & 11.05 \\
\hline 9 & Communications & DLO & 11.05 \\
\hline 10 & Director - Supply chain & QinetiQ & 12.05 \\
\hline 11 & Chief Engineer & QinetiQ & 03.06 \\
\hline 12 & Chief Engineer & MBDA & 04.06 \\
\hline 13 & Manager & Augusta-Westland & 04.06 \\
\hline 14 & Consultant & KPMG & 05.06 \\
\hline 15 & Director & DPA & 05.06 \\
\hline 16 & Director & BAE Systems & 05.06 \\
\hline 17 & Director (Retired) & Thales & 05.06 \\
\hline 18 & Director - Logistics & DLO & 06.06 \\
\hline 19 & Project Manager & BAE Systems & 06.06 \\
\hline 20 & Director & DCSA & 06.06 \\
\hline 21 & Senior training officer & Royal Marines & 06.06 \\
\hline 22 & Senior Manager & DPA & 07.06 \\
\hline & & DERA Defence Research \& Evaluation Agency \\
& & DPA Defence Procurement Agency \\
& & DLO Defence Logistics Organization \\
\hline
\end{tabular}


Table 2: Change in UK Defence Supply Relationships

\begin{tabular}{|c|c|c|c|}
\hline Theme & MoD Interviews & Supplier Interviews & Official Documents \\
\hline $\begin{array}{l}\text { Strategic partnerships } \\
\text { and shifting boundaries }\end{array}$ & $\begin{array}{l}\text { - Supply base reduction: contract } \\
\text { value increasing, numbers } \\
\text { decreasing } \\
\text { - Shift from fixed contracts to } \\
\text { dynamic boundary } \\
\text { - Relationship rather than } \\
\text { transactional contracts focus } \\
\text { - MoD outsourcing previous be core } \\
\text { activities } \\
\text { - Creating coherence between MoD } \\
\text { and industry } \\
\text { - Alignment of interests, gain and } \\
\text { sharing }\end{array}$ & $\begin{array}{l}\text { - Supplies single or dual source key } \\
\text { components. } \\
\text { - Some suppliers specified by MoD } \\
\text { so limited choice } \\
\text { - Relationship management of } \\
\text { suppliers and MoD } \\
\text { - Supplier development, but some } \\
\text { suppliers unclear how to proceed } \\
\text { - Strategic MoD suppliers } \\
\text { increasingly responsible for in- } \\
\text { service support but outsource to } \\
\text { contractors }\end{array}$ & $\begin{array}{l}\text { - Formal industry distinction } \\
\text { between 'partnering arrangements' } \\
\text { and 'partnering agreements' } \\
\text { - Partnership agreements between } \\
\text { MoD and BAE Systems, Wallop } \\
\text { Defence Systems, QinetiQ, and } \\
\text { Agusta-Westland } \\
\text { - MoD recently appointed Key } \\
\text { Supply Engagement Managers } \\
\text { (KESMs) }\end{array}$ \\
\hline $\begin{array}{l}\text { Through-life } \\
\text { Management (TLM) }\end{array}$ & $\begin{array}{l}\text { - MoD seek totality of support } \\
\text { - Potential issues with increasing } \\
\text { civilian support personnel over mid- } \\
\text { term deployment repair }\end{array}$ & $\begin{array}{l}\text { - Innovation increasingly means } \\
\text { technology or capability } \\
\text { insertion/upgrading on long-term } \\
\text { platforms: not development of new } \\
\text { platforms } \\
\text { - TLM significantly affects supplier } \\
\text { profitability as not selling parts but } \\
\text { providing availability and capability } \\
\text { - Design for maintainability: } \\
\text { platforms 'in-service' for several } \\
\text { decades } \\
\text { - TLM implies more interaction } \\
\text { between MoD and suppliers } \\
\text { - Contracting for availability/ } \\
\text { capability: critical distinction } \\
\text { - Not all suppliers understand } \\
\text { TLCM implications }\end{array}$ & $\begin{array}{l}\text { - Concept of Through-Life } \\
\text { Capability Management (TLCM) } \\
\text { central in recent reports } \\
\text { - TLCM based on open product } \\
\text { architectures, allowing upgrading } \\
\text { and support } \\
\text { - TLCM reflects shift from platform } \\
\text { programmes to support, } \\
\text { sustainability and enhancement of } \\
\text { existing capabilities from technology } \\
\text { insertions } \\
\text { - TLCM reflected in CADMID cycle: } \\
\text { Concept, Assessment, } \\
\text { Demonstration, Manufacture, In- } \\
\text { service, Disposal }\end{array}$ \\
\hline Transparency & $\begin{array}{l}\text { - Sharing of data and technology } \\
\text { with non-UK suppliers problematic }\end{array}$ & $\begin{array}{l}\text { - Lack understanding of cost drivers } \\
\text { - Open book policy will involve } \\
\text { considerable pain } \\
\text { - Historical mistrust between MoD } \\
\text { and suppliers }\end{array}$ & $\begin{array}{l}\text { - Encourage trust, openness, } \\
\text { transparency and communication at } \\
\text { all levels between MoD and } \\
\text { partnership suppliers } \\
\text { - MoD encourage sharing future } \\
\text { plans and priorities } \\
\text { - Transparency relates to MoD } \\
\text { capability intentions, affordability } \\
\text { constraints and desired outcomes }\end{array}$ \\
\hline $\begin{array}{l}\text { Mutuality, risk and } \\
\text { benefit sharing }\end{array}$ & $\begin{array}{l}\text { - Traditionally a disincentive for } \\
\text { suppliers to pay for repairs: MoD } \\
\text { want suppliers responsible for entire } \\
\text { product life } \\
\text { - Move towards planning around } \\
\text { whole-life costs and capability rather } \\
\text { than upfront purchase cost } \\
\text { - Fundamental shift in relationships: } \\
\text { shared processes and partnering }\end{array}$ & $\begin{array}{l}\text { - Industry must manage more risk } \\
\text { - More innovative approach to cost } \\
\text { and risk sharing: fixed price } \\
\text { insufficient }\end{array}$ & $\begin{array}{l}\text { - Use of incentivisation of gain } \\
\text { sharing to encourage industry and } \\
\text { MoD to improve performance }\end{array}$ \\
\hline
\end{tabular}


Figure 1: Typical cost profile during the CADMID cycle (Adapted: MOD 2005)

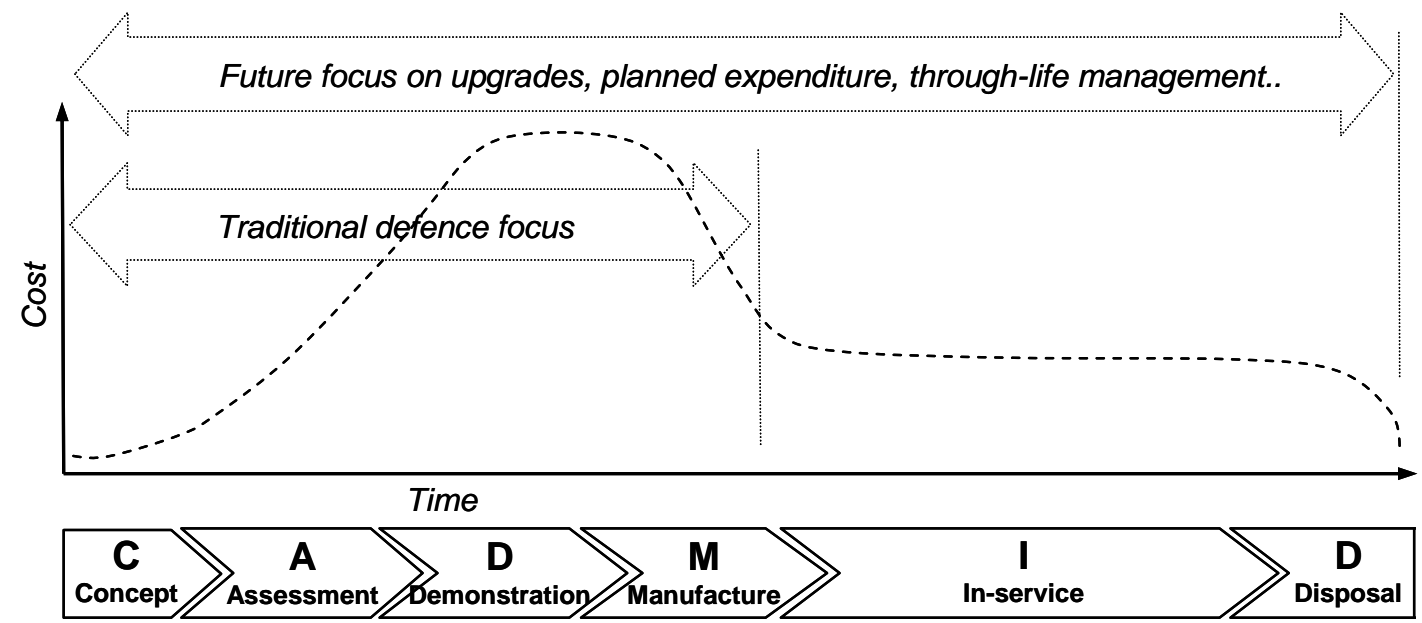


Appendix A: Semi-Structured Interview Questions

1. What are the key defence supply chains capabilities in terms of in-service support which will emerge over the next 5 to 10 years?

2. What does through-life capability mean to your organisation?

3. What does it mean to your customers and suppliers?

4. How does your organisation cope with changing patterns of demand from the military?

5. Do current military supply chain models address defence industry requirements?

6. What consideration is given to common product architecture and modularisation?

7. Have your purchases been consolidated?

8. Describe the supply chain capabilities for several technology platforms produced/managed by your organisation.

9. What is the future direction and requirement/s of defence procurement and supply? 